$\mathrm{Pb}^{2+}$ and $\mathrm{CrO}_{4}{ }^{2-}$ ions were noted in each experiment. The best reduction was noted in anaerobic light conditions. (Adenij, 2004).

From the above discussion and analysis it could be concluded that Rhodobacter sphaeroides is a metabolically diverse species, being capable of growing in a wide variety of growth conditions. It can be used commercially on a large scale to treat both industrial and municipal waste water. The best growth conditions for the species were found to be anaerobic light conditions, where its oxidizing impact becomes intense.

Bioremediation, using $R$. sphaeroides can be a cost effective and environmental friendly way to treat the contaminated sediments.

\section{Acknowledgment}

The authors are thankful to the principal, B.S.A. (P.G.) College, Mathura for providing the facilities required.

\section{References}

Adenij, A. 2004. Bioremediation of arsenic, chromium, lead and mercury. Environmental Protection Agency (U.S.), 540. pp 20-33.

APHA 1989. Standard methods for the examination of water and waste water. $17^{\text {th }}$ Ed. Washington. D.C., U.S.A. pp. 10-203.

Bergey, D.H. and J.G. Holt 1994. Bergey's manual of determinative bacteriology. Lippin cott Williams and Wilkins. $9^{\text {th }}$ Ed. pp. 161-167.

Neil, R.B., J.K. Cristopher, J.B. Michael and K.V. rajagopalan 1991. Spectroscopic studies of the Molybdenum containing Dimethyl sulphoxide reductase from Rhodobacter sphaeroides $\mathrm{sp}$. denitrificans. J. Biol. Chem. 266(1): 45-51.

\title{
Effect of Different Concentrations of Sewage on the Haematological Parameters of Cirhinus mirghala of Jalla (Pan) of Patna City
}

\author{
N.P. Tiwary ${ }^{1}$, S.K. Das ${ }^{1}$, R.R. Prasad ${ }^{1}$, S.K. Gupta ${ }^{1}$, J. Kumar ${ }^{1}$ and R. Kumar ${ }^{2}$ \\ ${ }^{1}$ College of Commerce, Patna, India \\ ${ }^{2}$ Parvati Science College, Madhepura, India
}

Received: 21.01.2009, Accepted: 09.04.2009

Key words: Sewage, Jalla (Pan), Patna City, Cirhinus mirghala, Haematological parameters

The Jalla (Pan) is situated in Patna city $\left(25^{\circ} 37^{\prime} \mathrm{N} \& 85^{\circ} 12^{\prime} 31^{\prime \prime} \mathrm{E}\right)$. The feeding of pond is mainly through the sewage from the urbanized catchments area. The water is thus loaded with very high concentration of nutrients. The physico-chemical characters of raw sewage were analyzed as per APHA (1985). Juveniles of Cirhinus mirghala (2.5 f $0.5 \mathrm{~g}$ live weight) were procured and acclimated to laboratory conditions for a period of one month in de-chlorinated tap water. During the acclimation period; the fish were fed on pelletted feeds with 38\% protein level. After characterization and static bioassay of the domestic sewage, the test fishes were exposed to chosen sublethal levels (50 to 100\%) of domestic sewage which was taken in the plastic 
Our Nature (2009) 7

Table 1. Physico-chemical and biological parameters of raw sewage at the inlet point (Average of weekly samplings for one year).

\begin{tabular}{|c|c|c|c|}
\hline Parameters & Raw sewage & Parameters & Raw sewage \\
\hline$\overline{\mathrm{pH}}$ & 8.25 & Total phosphorus (as P) & 4.35 \\
\hline Temperature ${ }^{\circ} \mathrm{C}$ & 29.0 & Dissolved phosphorus (as P) & 2.67 \\
\hline Total dissolved solids & 865 & $\mathrm{Zn}$ & 3.52 \\
\hline Total suspended solids & 162 & $\mathrm{~Pb}$ & 0.21 \\
\hline Dissolved oxygen & 1.02 & $\mathrm{Cu}$ & 0.64 \\
\hline Dissolved carbon-di-oxide & 62.75 & $\mathrm{Cr}$ & 0.12 \\
\hline $\mathrm{BOD}_{5}\left(\right.$ as $\left.\mathrm{O}_{2}\right)$ & 285 & Total bacteria $10^{6} \mathrm{ml}^{-1}$ & 6.42 \\
\hline Ammonia nitrogen & 1.89 & Coliforms $10^{4} \mathrm{ml}^{-1}$ & 7.38 \\
\hline Nitrite nitrogen & 0.0025 & Salmonella $\times 10^{3} /^{-1}$ & 32.00 \\
\hline Nitrite nitrogen & 0.57 & Faecal streptococci $\times 10^{2} /^{-1}$ & 5.72 \\
\hline Total nitrogen & 2.68 & & \\
\hline
\end{tabular}

All values in $\mathrm{mg}^{-1}$, otherwise stated.

Table 2. Blood parameters of G. mirghala.

\begin{tabular}{|c|c|c|c|c|}
\hline Blood parameters & Exposure days & Control & $50 \%$ & $100 \%$ \\
\hline \multirow{5}{*}{ RBC (Total) $\times 10^{6} \mathrm{~mm}^{-3}$} & 0 & 4.58 & 4.4 & 4.1 \\
\hline & 30 & 4.49 & 4.36 & 4.06 \\
\hline & 60 & 4.38 & 4.25 & 3.94 \\
\hline & 90 & 4.55 & 4.18 & 3.88 \\
\hline & 0 & 13.29 & 12.94 & 12.11 \\
\hline \multirow{4}{*}{ Haemoglobin $(\%)$} & 30 & 13.26 & 12.91 & 12.08 \\
\hline & 60 & 12.78 & 12.52 & 11.65 \\
\hline & 90 & 13.04 & 12.41 & 11.54 \\
\hline & 0 & 66.31 & 64.87 & 60.87 \\
\hline \multirow{4}{*}{ Haematocrit (\%) } & 30 & 66.25 & 64.6 & 61.35 \\
\hline & 64 & 65.15 & 63.9 & 59.6 \\
\hline & 90 & 66.35 & 63.63 & 59.49 \\
\hline & 0 & 14.48 & 14.74 & 14.85 \\
\hline \multirow{4}{*}{$\operatorname{MCV}(\mathrm{R})$} & 30 & 1476 & 14.82 & 15.11 \\
\hline & 60 & 14.87 & 15.04 & 15.13 \\
\hline & 90 & 14.63 & 15.22 & 15.33 \\
\hline & 0 & 29.02 & 29.41 & 29.54 \\
\hline \multirow{4}{*}{$\mathrm{MCH}(\mathrm{pg})$} & 30 & 29.53 & 29.61 & 29.75 \\
\hline & 60 & 29.18 & 29.46 & 29.57 \\
\hline & 90 & 28.66 & 29.69 & 29.74 \\
\hline & 0 & 20.04 & 19.95 & 19.89 \\
\hline \multirow{3}{*}{$\mathrm{MCHC}\left(\mathrm{g} l^{-1}\right)$} & 30 & 20.02 & 19.98 & 19.69 \\
\hline & 60 & 19.62 & 19.59 & 19.55 \\
\hline & 90 & 19.59 & 19.5 & 19.4 \\
\hline
\end{tabular}

troughs of 301 capacity. Ten fishes were introduced into each trough and triplicates were maintained in each concentration. The test fish reared in de-chlorinated tap water served as control.
Haematological studies were carried out at the $30^{\text {th }}, 60^{\text {th }}$ and $90^{\text {th }}$ day of exposure. Methods described by Hesser (1960) for routine fish haematology were followed to estimate all blood parameters in this study. 


\section{Our Nature (2009) 7}

Red cell indices were worked out using the formula suggested by Johannson-Sjobeck and Larson (1978).

The physico-chemical characteristics of domestic sewage were given in Table 1 . The different blood parameters of control and sewage treated fishes are shown in Table 2. The total red cell counts, $\mathrm{Hb}$ content, PCV and MCI-IC were found to be significantly reduced in the test animal, on exposure to different sub-lethal concentration of domestic sewage. Dose and time-dependant changes were observed on all the blood parameters. Similar observations were made by Sambasiva Rao et al. (1985) in fishes treated with pesticides, by Subramaniam et al. (1988) in fishes exposed to tannery effluent and by Izuru (1997) in fishes exposed to raw and treated sewage. On the other hand, the mean corpuscular volume (MCV) showed gradual increase in relation to sewage concentration and exposure period.

Exposure of the test animals for 30, 60 and 90 days to sub-lethal concentrations of domestic sewage caused significant reduction in total $\mathrm{RBC}$ count, haemoglobin content and haematocrit value leading to anemia. Since the red cell indices like MCHC show gradual reduction during exposure period, the anaemic condition can be classified as microcytic and hypochrotnic anaemia (Johannson-Sjobeck and Larson, 1978). The anaemic effects in fishes are variously attributed to the inhibition of erythrocyte production (Larsson et al., 1976) or haemodilution (Mcleay, 1973) or coagulation of blood following destruction of intestinal cells (Johannson-Sjobeck and Larson, 1978) or destruction of liver cells (Waluga, 1966). In the present study, the anaemic effects may be due to both reduction in the number of erythrocytes and haemoglobin content of each cell as indicated by a marked decrease in MCHC value. The significant reduction in total RBC count may be attributed to the destruction of red cells by pollutants, because significant increase in $\mathrm{MCV}$ is considered to be the indices of red cell destruction leading to anaemia (JohannsonSjobeck and Larson, 1978).

An increase in the number of immature $\mathrm{RBC}$ in sewage treated individuals precludes the possibility of inhibition of erythropoietin. The increase in the number of circulating immature erythropoiesis by elevated demands of $\mathrm{O}_{2}$ and $\mathrm{CO}_{2}$ transport in sewage exposed fish as a result of physical and metabolic activity. Thus, the present study clearly reveals that the domestic sewage affects the blood parameters of the test animals at higher concentration.

\section{References}

APHA 1985. Standard methods for the examinations of water and wastewater. $18^{\text {th }}$ Ed. Inc., New York.

Hesser, E.F. 1960. Methods for routine fish haematology prog. Fish-cult. 22: 164-171.

Izuru, K. 1997. Environmental toxicology and water quality. John Willey and Sons, ISSN. 1053-4725. 12: 43-51.

Johannson-Sjobeck, M.K. and A. Larson 1978. The effect of Cadmium on the haematology and on the activity of amino-levulinic acid dehydralase (ALA-11) in blood and

haemopoeitic tissues of the flounder Plueronectes flesus L. Environ. Res. 17: 191204.

Larsson, A., Bengtsson and D. Svanberg 1976. Some haematological and bio-chemical effects of Cadmium on fish. In Effects of pollutants on Aquatic organisms (Ed. A.P.M. Lockwood). Soc. Exp. Bio. Sem. Ser. Cambridge University Press. Cambridge. 2: 35-45.

Mcleay, U.J. 1973. Effects of 12 h and 25 days exposure to Kraft Pulp Mill effluent on the 
blood and tissues of juvenile Coho salmon. $J$. Fish Res. Bd. Can. 30: 395-400.

Sambasiva Rao, K.R., K.S. Prasada Rao, I.K. Ahaned Sahib and K.V. Raman Rao 1985. Combined action of carbaryl and phenthoate on a fresh water fish. C. puncatus (Bloch.).

Ecotoxicol. Environ. Saf. 10: 209-217.

Subramaniam, M.A., M.S. Hameed and G.
Varadaraj 1988. Haematological changes in the fish Macrones keletius (Gurther) after exposure to the tannery effluent. The Indian Zoologist 12: 71-74.

Waluga, D. 1966. Phenol effects on the anatomical and histopathological changes in bream (Abramis brama L.). Acta. Hydrobiol. $8: 55-78$.

\title{
On Some Diatoms from Upper Mustang Trans-Himalaya Region, Nepal
}

\author{
B.R. Subba ${ }^{1}$, M.R. Pandey ${ }^{2}$, K.P. Limbu ${ }^{1}$ and S.K. Rai ${ }^{3 *}$ \\ ${ }^{1}$ Department of Zoology, P.G. Campus, T.U., Biratnagar \\ ${ }^{2}$ National Trust for Nature Conservation, Annapurna Conservation Area Project, Unit Conservation Office, \\ Jomsom. \\ ${ }^{3}$ Department of Botany, P.G. Campus, T.U., Biratnagar \\ "E-mail: shivarai2003@yahoo.com
}

Received: 07.11.2009, Accepted: 25.12.2009

Key words: Algae, Diatoms, Upper Mustang Trans-Himalaya, Nepal

A total 19 diatom taxa viz. Achnanthes flexella (Kütz.) Brun., Amphora libyca Ehr., Cymatopleura solea (Bréb.) W. Smith, Cymbella affinis Kütz., Cymbella cistula (Ehr.) Kirchn., Cymbella helvetica Kütz., Cymbella radiosa Reichelt, Denticula elegans Kütz., Diatoma hiemale (Lyngb.) Heib., Gomphonema clavatum Ehr., Hannaea arcus var. arcus (Ehr.) Patrick in Patrick \& Reimer, Navicula cuspidata Kütz., Neidium affine (Ehr.) Pfitzer, Pinnularia viridis (Nitzsch) Ehr., Rhopalodia gibba (Ehr.) O. Müller, Staurosirella leptostauron (Ehr.) Williams \& Round, Surirella linearis W. Smith, Surirella spiralis Bréb. and Synedra ulna (Nitz.) Ehr. under 15 genera were recorded from Upper Mustang Trans-Himalaya region, Nepal (Figs 1-22). Among these, Cymbella, Diatoma, Hannaea and
Pinnularia spp. were the most abundant genera whereas genera like Amphora, Gomphonema and Neidium were rare.

Upper Mustang (28 $47^{\prime} 39^{\prime \prime}$ to $29^{\circ} 19^{\prime} 54^{\prime \prime} \mathrm{N} \& 83^{\circ} 28^{\prime} 55^{\prime \prime}$ to $84^{\circ} 15^{\prime} 16^{\prime \prime} \mathrm{E}$ ) occupies almost half of the area (ca 2567 $\mathrm{km}^{2}$ ) of northorn Mustang district in the Trans Himalayan region of Nepal, north to the Himalayan range (Map 1). It is bordered by Tibet of China, Dolpa district, Manang district and southern mountains in the north, west, east and south respectively. There are seven VDCs viz. Chhoser, Chhonup, Lo Manthang, Tsarang, Surkhang, Ghami and Chhuksang in which several freshwater streams and rivers flow originating from Himalayas and high mountains. The rocks are mainly metamorphic type comprising conglomerates, granite etc. and most of the observed rocks across the Kali Gandaki 